\title{
Talent Management in Academia - The Indian Business School Scenario
}

\author{
Rajiv Divekar ${ }^{1} \&$ Ramakrishnan Raman ${ }^{2}$ \\ ${ }^{1}$ Symbiosis Institute of Management Studies, Symbiosis (Deemed University) Lavale, Pune, India \\ ${ }^{2}$ Symbiosis Institute of Business Management - Pune, Symbiosis (Deemed University) Lavale, Pune, India \\ Correspondence: Rajiv Divekar, Symbiosis Institute of Management Studies, Symbiosis (Deemed University) Lavale, \\ Pune, India.
}

Received: October 12, 2019

Accepted: January 6, 2020

Online Published: January 17, 2020

doi:10.5430/ijhe.v9n2p184

URL: https://doi.org/10.5430/ijhe.v9n2p184

\begin{abstract}
This paper explores the gamut of human resource practices prevailing in private Indian Business Schools (B Schools) with specific focus on the talent management strategies adopted. The paper explores the interdependence of talent management strategies adopted by the private Indian business schools and the organisational strategy along with the metrics and scales used to measure the academic performance. The paper analyses and critiques the present scenario for lacking alignment between the vision vis-à-vis the strategies adopted for talent recruitment, talent development and retaining and rewarding talent. The paper debates on the fact that prudent talent management can help in developing a conceptual framework to augment performance of B Schools over long term by amalgamating the B school's strategy with its performance metrics.
\end{abstract}

Keywords: talent management, B school, human resource management, strategy

\section{Introduction}

Over the past few years, higher education landscape in India has undergone a steady change which has impacted the Indian B Schools. This change was driven driven by the Ministry of Human Resource Development (MHRD), the University Grants Commission (UGC) and the All India Council for Technical Education (AICTE). Changes in policies, procedures, rules, establishment of mandatory compliances, introduction of National Institutional Ranking Framework (NIRF) for ranking Indian business schools, grant category status and revamping the process for accreditation are some of the actions initiated by MHRD and UGC. The basic intent and purpose of all these changes was to improve the quality of education and make it more outcome based which is in tune with the requirement of the day. Another objective was to bring about these changes which could to standardize education to a great extent which facilitates migration, credit transfer, credit equivalence which can help students at large. The Indian government is trying to bring transparency, ensure accountability and objectivity in B school education and bring it on par in terms of quality with those B schools in the United States and other developed nations.

The ability to attract and retain the best talent has become a vital human resource management issue for educational institutions across the globe. (Huisman et al., 2002; Metcalf et al., 2005; Kubler and DeLuca, 2006). Numerous survey and studies indicate that several academic disciplines, across several countries, face an acute shortage of talent. (Gilliot et al.,2002; Van Balen \& Van den Besselaar, 2007; Lubbe and Larsen, 2008; Edwards and Smith, 2010). Many Universities are now looking at managing human resources from a strategic perspective (Deem, 2001). Talent management encompasses a wide range of human resource practices with a focus on recruiting, managing and retaining talent. (Lewis \& Heckman, 2006). Good quality academic fraternity is of paramount importance for high quality education to be delivered (Lorange, 2006). Higher education institutions and Indian B Schools are also adopting to use individual performance indicators to understand the potential contributions made by faculty members(Basu, 2006; Tijssen et al., 2002; Van Raan, 2005;). While the usage of these systems is slowly gaining popularity, they also have drawn criticism for their use and effectiveness (Lorange, 2006). Their use in recruitment is still being researched-(Nkomo, 2009; Özbilgin, 2009; Parker \& Jary, 1995; Van den Brink \& Benschop, 2011). Literature indicates that managing human resources in a strategic fashion is positively correlated with the performance of any organisation and hence this would also be applicable to Indian B Schools. (Delaney \& Huselid, 1996).

This paper explores the gamut of human resource practices prevailing in private Indian Business Schools with specific focus on the talent management strategies adopted. The paper explores three aspects namely- a) the sync between talent management strategies adopted by the private Indian business schools and the organisational strategy 
b) the sync between talent management strategies adopted by the private Indian business schools and with the metrics and scales used to measure the academic performance. The paper analyses and critiques the present scenario for lacking alignment between the organisational strategy vis-à-vis the strategies adopted for talent recruitment, talent development and retaining and rewarding talent. The paper debates on the fact that prudent talent management strategy in sync with the organisational strategy can augment performance of B Schools over long term. Amalgamating the B school's strategy with its performance metrics and day-to-day management systems can immensely benefit the B School in long run.

\section{B School Education - The Indian Context}

There are several regulatory bodies that regulate the higher education in India. Universities awarding their own degrees are classified into five types and are based on the management that controls them. The five categories are Central University, State University, Private University, institutions deemed to be a University, and Institutes of National Importance. Colleges can award degrees in the name of the university to which they are affiliated. There are approximately 15 professional councils such as the Medical Council of India (MCI), the All India Council for Technical Education (AICTE), the Bar Council of India (BCI), the National Skill Development Council (NSDC), and the Indian Nursing Council (INC) that regulate the professional and skill based courses run by the colleges and universities. The University Grants Commission (UGC) acts as the supreme regulatory body set up by the Indian Union government in accordance to the UGC Act 1956 under the Ministry of Human Resource Development (MHRD), and is responsible for maintenance of standards in higher education. There are two accrediting institutions - the National Board of Accreditation (NBA) established by AICTE, and the National Assessment and Accreditation Council (NAAC) established by the UGC which accredit institutions. There are also private accrediting institutions including the Association to Advance Collegiate Schools of Business, also known as AACSB International, and the EFMD Quality Improvement System (EQUIS) run by the European Foundation for Management Development (EFMD) that rate higher educational institutions and programmes. There are two major ranking of higher education institutions in the country which are approved by MHRD. They are the National Institutional Ranking Framework (NIRF) and the Atal Ranking of Institutions on Innovation Achievements (ARIIA). Apart from these two there also other private institutions such as The Times Higher Education World University Rankings, Quacquarelli Symonds (QS) ranking which rank B Schools and other higher education institutions.

NIRF is a methodology adopted by the Ministry of Human Resource Development (MHRD), Government of India, to rank institutions of higher education in India. ARIIA is an initiative of the Ministry of Human Resource Development (MHRD), Govt. of India to systematically rank all major higher educational institutions and universities in India on indicators related to "Innovation and Entrepreneurship Development" amongst students and faculty members. As the structure is very complex, it becomes all the more important for B Schools to brand and communicate with the aspirants, as it is imperative for them for their growth and survival (Harsha \& Shah, 2011)

In the B School education landscape, the first management program in the full-time mode was started in 1957 by Andhra University. After anticipating the demand for management education, the All India Institute of Management and Social Welfare, Kolkata and Delhi University introduced the management programs in 1958. The government of India set up the first B school named in Indian Institute of Management (IIM) at Calcutta in 1961 and this was in collaboration with the Sloan School of Management (MIT). The next IIM was set up at Ahmadabad in 1962, in collaboration with Harvard Business School. Later many private business schools were established and the government also started many more IIMs across India. IIMs were established in Lucknow, Indore and Kozhikode by the end of 1990s (Sinha, 2006). In the late 90's to early 2000 there was an explosive growth of Indian B Schools and almost 1940 were functional in India by 2010 (Kumar \& Dash, 2011). Post economic liberalization in 1991, there was a huge demand for qualified management graduates to run and manage business enterprises and this led to the exponential growth of B Schools across India. With The growth in the middleclass and a competitive job market made it possible for B School to be looked at as a business opportunity by affluent investors, and this fuelled a bubble in the business education market space (Shah, 2012).

As of July 2019, 20 IIMS and more than 3500 B Schools operate in India. IIMs select students based on an all India entrance examinations named the Common Aptitude Test (CAT), and a few hundred million students appear for examination and this occurs due to the pride associated with pursuing a Master in Business Administration from these premier institutions. There are also several reputed private B Schools in the country which accept the scores of the CAT, but there are others who have their own examinations, such as the Xavier Aptitude Test (XAT)-and the Symbiosis National Aptitude Test (SNAP). These examinations also attract a few hundred million students who take up the exam with an aspiration to join the top private B schools in the country. Many of the schools face acute 
shortages of good faculty members and there are several reasons which attribute to this shortage.

\section{Faculty Shortage - The Indian B School Scenario}

Indian B Schools operate in a complex, dynamic and highly competitive environment. B Schools are continually looking for qualified faculty members who can teach, research and take up administrative responsibilities. As baby-boomers are leaving the profession due to their age, the scarcity of academic talent in Indian B Schools is a now bigger problem getting (Musselin, 2005; Shaikh, 2009; Verhaegen, 2005;).

The Indian B Schools - both private and public - continually have a shortage of full-time qualified faculty members who can teach and mentor students. One reason is the inadequate supply of qualified faculty members - as per the mandate given by UGC which gives the minimum eligibility criteria to hire a faculty member - who can teach in a B School. UGC mandates that B Schools should have faculty members as per a standards faculty student ratio. UGC also mandate that assistant professors should have a doctoral degree or must be qualified for the National Eligibility Test (NET) conducted by the Government of India in the specific discipline. The students who join the B School expect faculty members to have an understanding of the industry and provide inputs on what's happening in the industry. Whereas the management and administrators prefer that faculty members have excellent research output along with a good mix of industry and teaching experience. Another reason for the shortage of full-time qualified faculty members is the pay structure that prevails, which is not as lucrative as the industry pay structures, which drives away good talent from choosing this profession. Some private B schools also prefer to hire practicing managers as visiting faculty members in a part-time mode so as to cut on costs and concurrently give an exposure to standard industry practices to students.

B School education is a social science which educates students on how to manage people, creating and manage process, technology, products and services (Harsha \& Shah, 2011). Thereby only by learning theory cannot help students to be successful and hence practical experience and experiential learning can help in making them get prepared to face the industry. While theory is essential to understand the fundamentals of management, knowledge gained through case studies, role plays, live projects, and exposure to corporate completions is of paramount importance (Van Raan 2005). This is where the MHRD and UGC policies, rules, procedures, guidelines are at cross purpose with management teaching. Management education is different from Engineering, Science, Commerce which are more theory and formula-based. Management education requires teachers who are practitioners working in industry as they bring with them the requisite industry knowledge. This makes B Schools to look out for talent who are qualified as per UGC norms, along with the exposure to the industry and with a good research profile - as finding such talent at the salary structures offered is a mammoth task, shortage of academic talent is a perineal problem for Indian B Schools.

\section{Vision - Organisational Strategy - Talent Management Strategy}

A vision statement of a B School defines the final objective or the purpose for which the B School exists. It also indicates where the B school aspires to go / become by setting a defined direction for the growth of the B school. Unlike operational goals, vision statements undergo minimal revisions during the life of any business, and this is applicate to higher education institutions including Universities and B Schools. It is imperative for the vision statement to be paired with all initiatives, so that the essence of the vision is communicated and reinforced. All processes must be aligned to the vision to ensure every internal stake holder acts in the apt fashion, which is in line with the vision-(Kantabutra and Avery, 2010).

According to Porter (1985), strategy is all about making choices. For an organisation to have strategic competitive advantage, the organisation must have a clear vision along with a strong organisation strategy. The organisation must invest in resources needed to nurture key competencies leading to long term superior performance and growth. An organisational strategy will be derived from the vision and mission statements which gives the reason for existence of the business. All activities of the organisation will have to be in sync with the vision and mission of the organisation. Hence an organizational strategy is the sum of the actions a company intends to take, in order to achieve long-term goals.

As organisations have vision statements, many Indian B Schools have vision statements and they are generally displayed on their websites. While all B Schools educate and train students in business management and allied domains, their vision and strategies are not identical. As per the principles of business, it is expected from B schools that their vision drives their organisational strategy. For example, the organisational strategy may involve focusing on internationalisation or development of particular skill sets such as leadership, communication or even focus on creating entrepreneurs based on the vision of the B school. 
The existing literature on talent management provides many definitions to the term 'Talent Management' and it has been found that it is imperative for any organisation to align the human resource management strategy, talent management strategy to its organisational strategy (Armstrong, 2006; Ashton \& Morton, 2005; Ingham, 2006; Lewis \& Heckman, 2006 ; McCauley \& Wakefield, 2005; Sahoo \& Mishra, 2012). The objective of talent managementfrom a B School perspective- is to is to hire, manage, develop, and retain talented faculty members, which is in sync with the vision of the B school.

\section{Methodology}

To know the vision and understand the talent management strategies adopted by private Indian business schools, the secondary data published on websites and talent management practices available in the public domain (off and online) have been considered. The authors have considered private business schools which are listed in the top 50 in the year 2019, by the National Institutional Ranking Framework (NIRF). NIRF is a framework approved by the Ministry of Human Resource Development (MHRD) Government of India, to rank Indian higher educational institutions. Also the policy guidelines given by University Grants Commission (UGC) and All India Council of Technical Education (AICTE) for talent recruitment, talent development, retaining and rewarding talent have been taken into consideration. The authors have taken exploratory research approach. Hence the methodology is flexible and investigative. A mix of qualitative and quantitative method is used to gather information and does not involve testing of hypotheses.

\section{Analysis}

\subsection{Vision Statement and Recruitment Statement}

Private B Schools in the top 50 B Schools of NIRF S School ranking 2019 were considered and their vision statements were taken from the website of the respective B schools. An analysis of the vision statement of B Schools showed that the majority of B Schools emphasise creating leaders who are equipped to run business and are socially responsible, and who have knowledge on global/international practices. A word cloud was created using the vision statement of the business schools as shown in the Figure 1. The world cloud was created using https://wordart.com/create which provides free tool for word cloud creation. Figure 1 clearly depicts that high emphases is on words like 'leaders', 'business', 'socially', 'global', 'developing', 'education', and medium to low emphasis on 'teaching', 'research', 'teaching', 'development', 'quality', 'learning', and 'innovate'.

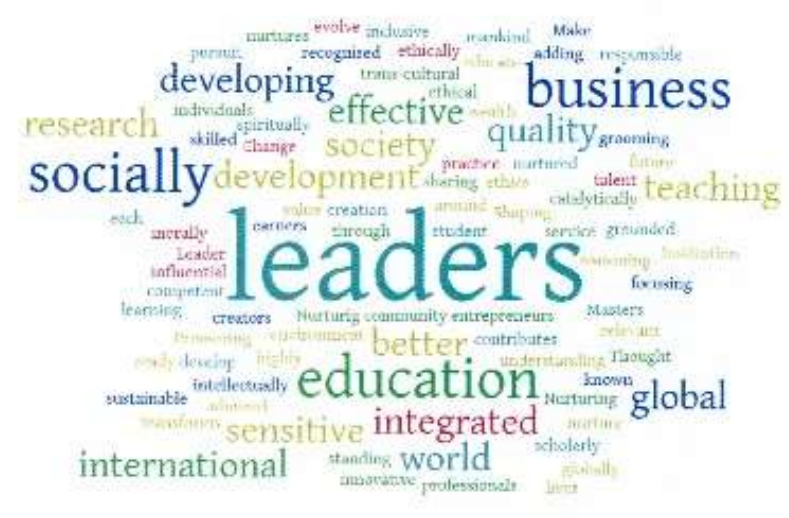

Figure 1.

The same set of B Schools were considered and their recruitment / call for talent to join their institution were taken from the website of the respective B schools. An analysis of the advertisements showed that the majority of B Schools emphasise on recruiting people with research backing and those who have published papers in reputed journals listed in Scopus and Australian Business Deans Council (ABDC) database of journals. Almost all B Schools are searching for faculty members who have a good qualification along with a great publication track record with teaching, training and consulting experience. A word cloud was created using the statements which were displayed by B Schools in the website career section and the same is shown in the figure 2 was created using https://wordart.com/create. The figure 2 depicts clearly that high emphases is on words like 'Research', 'Paper', 'Publication', 'Scopus', 'ABDC', 'Teaching', and medium to low emphasis on 'Creative', 'Leaders', 'Talent', 'Social', 'Global', and 'Innovation'. 


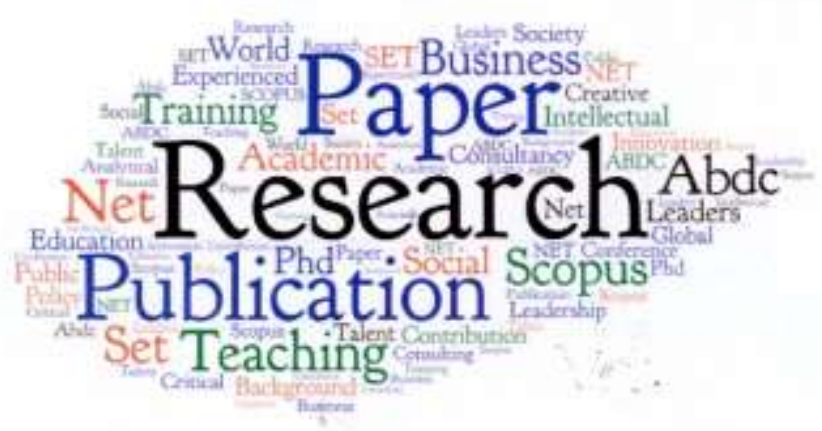

Figure 2.

\subsection{Vision of B School and Norms of Regulatory Agencies}

Management education in India is governed by different regulatory agencies and types of agencies that regulates an institution depends on the type of the educational institution. The UGC stipulates the norms for recruitment of faculty members in a B School that is affiliated to a University whereas the All India Council for Technical Education (AICTE) provides guidelines for faculty recruitment to B Schools that are autonomous and have the AICTE approval to offer the post graduate diploma program in management. The Ministry of Human Resource Development (MHRD) provides the overarching policy guidelines to Universities and Deemed Universities in India.

As per the UGC guidelines (2019), the National Eligibility Test (NET), or the State Eligibility Test (SET) or PhD is mandatory for being appointed as an Assistant Professor in a B School, whereas as per the ACITE guidelines, a Bachelor's Degree in any discipline and Master's Degree in Business Administration or equivalent with First Class honors or equivalent, and two years of professional experience after acquiring the degree of Master's degree is sufficient to be recruited as an Assistant Professor. A recent guideline provided by MHRD indicates that a PhD would become mandatory to be recruited as an Assistant professor in a University (MHRD, 2019). While the creation of the vision of a B School is not regulated by these agencies, who can be recruited as faculty members and who can be admitted as a student in the B School is regulated by the regulatory authorities. Although the regulatory agencies stipulate the minimum requirement to recruit teaching faulty they do not reprimand for exceeding the requirements. Many B Schools focus on meeting the minimal requirements as stipulated by the regulatory agency, and also focus on research and publications as one of the important aspect, as research is considered as one of the most important factor by the ranking agencies (Goodall, 2009). This translates in their call for talent advertisements which can be seen in Figure 2, and hence there is a gap that is created between the vision of the B School and the talent that is recruited.

There are also norms for career advancement of teaching faculty members which are given by the UGC and AICTE. The UGC provides details on the on the minimum requirements which depend upon the Academic Performance Indicators (API) of faculty member's career advancement scheme (CAS) norms. The CAS norms takes the teaching work load, research output and other teaching and learning activities taken by the faculty members along with the number of years the faculty spends in a specific position and at a specific pay band. AICTE also gives some guidelines on career advancement and it largely focuses on the number of years that faculty members spend in a particular pay band for them to be considered for promotion to the next level. Several B Schools look at these norms while deciding on the promotion, and talent retention strategies are also intervened to these norms which are set by the regulatory agencies. This makes the talent recruitment and talent retention strategies to be aligned with the polices of the regulatory agencies rather than the vision of the B School.

\subsection{Vision Takes a Back Seat and Ranking Becomes the Fore Runner}

There are several ranking agencies which rank Indian B Schools. Many Indian magazines run their ranking surveys and come up with their B School ranking. There are also global players like the Quacquarelli Symonds (QS)-and the Times Higher Education (THE) which rank Indian B Schools. In 2015, the government of India devised the National Institutional Ranking Framework (NIRF), which is a methodology adopted by the Ministry of Human Resource Development (MHRD), Government of India, to rank institutions of higher education in India. The Framework was approved by the MHRD and launched by Minister of Human Resource Development on 29 September 2015 (NIRF 2019). Many Indian B Schools participate in this ranking and it has become a the most acceptable B school ranking 
by the academic and the student community.

While all the global ranking agencies look at several aspects of a B School, research out by the B School becomes one of the most important aspect to be considered. The Indian B School ranking by NIRF also takes - Teaching Learning \& Resources, Research and Professional Practice, Graduation Outcome, Outreach \& Inclusivity and Perception as the parameters. Forty percent weightage is given to Research and professional practice. While many B Schools have the vision to create global managers and leaders their standing in the B School ranking will determine the brand image that the B School creates among the academic peers, corporate and also the prospective students. This is also making many B School to focus on research output irrespective of the vision or the mission of the B School. Many B School offer a huge incentive for research and publication. The strategizes to reward talent are also based on the research output given by the employee and other aspects like ability to teach, ability to lead and administer are given very less importance.

Studying HR manuals of some private B Schools it was found that B Schools pay incentives,-to the tune of several millions, for publishing in reputed journals. B Schools also pay a differential pay package to attract teaching faculty members who have high research citation. Facilities extended, fringe benefits given, emoluments offered, incentives paid are all significantly higher to those who have higher research output when compared to those who are effective in teaching in the classroom or those who take administrative roles which are critical and are in line with the vision of the B School.

\section{Discussions}

India several B Schools have traditionally focused on teaching and consulting. Research has been a recent addition to the focus, and has been gaining a lot of importance by B school ranking agencies (Van Raan 2005), yet no compelling evidence to prove that the research activities of B School improves the educational outcome of the students graduating from the B School (Bradley et al., 2008). Globally the research output has been one of the most important factor that distinguishes leading global B Schools from their peers in terms of philanthropic funding (Goodall, 2009). Similar to the students seeking admissions to B School across the globe, the Indian students consider to join a B Schools by considering the brand image, fee charged, and the reputation of the B School (Abbot $\&$ Ali, 2009). In addition to this the placement opportunities that the B School provides also becomes one of the most important aspect considered by the aspirants while selecting the B School to pursue their management education. Hence both teaching and research must be focused along with the alignment with the vision of the B School, which is critical and important for the long term success of the B School. From a talent management perspective, B Schools must focus on talent who can contribute to teaching and consulting activities who can help to create global managers who can not only be industry ready but also industry leading. B Schools must also focus on talent who are good in creating knowledge and good in their research output.

Typically, from a talent recruitment perspective, B School must recruit, reward and retain talent both for academic (teaching \& consulting) and research activities. This structure, shown in Figure 3 below must be adopted which can help create a talent pool who can drive the B School's mission and also help in achieving the vision, while ensuring the regulatory requirements are met and the talent recruited also helps in achieving good B school ranking.

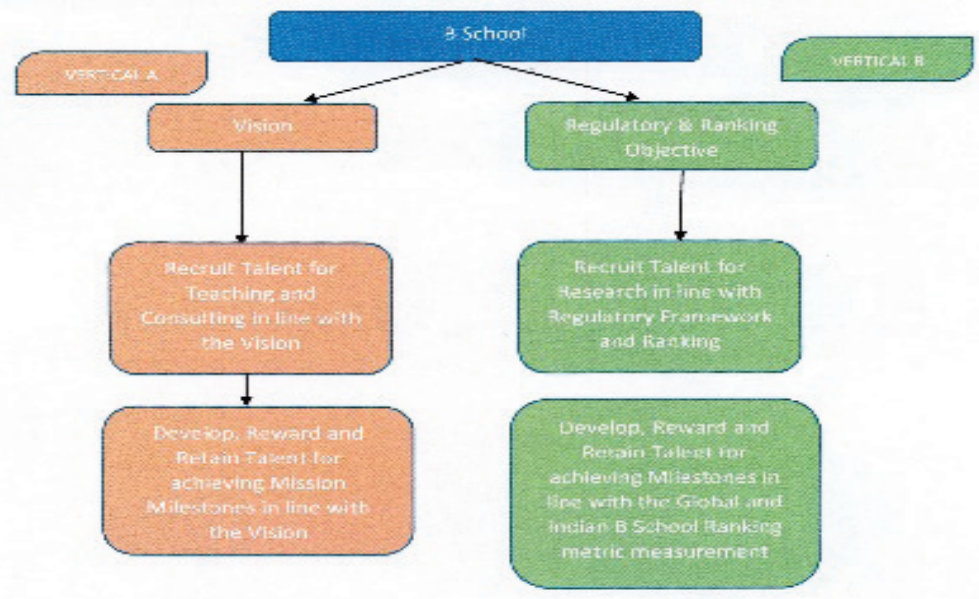

Figure 3. Talent management strategies for talent recruitment, talent development and retaining and rewarding talent - A Framework 
This structure must be adopted across all the departments and explicit leadership roles will be required at pivotal positions for successful implementation of the b school's strategy. In case the B School is able to tweak its vision and make research agenda as an integral part of its vision then this structure can be merged into one.

The structure reflected in Figure 3 will be of immense value as B Schools have many new roles that have been created in the recent past at the executive level to manage new portfolios which are of strategic importance. In many B Schools roles such as corporate development executive, placement officer, and international development executive, are also handled by faculty members and they don't have a focus and competence for research and publication. While these roles are of great importance, these will not add any value from a research perspective and will not help in increasing the research score of the B School. These roles have a chance to overlap with the core activities of teaching and research, as both teaching and research involve external engagement with both domestic and international partners, clients and stakeholders. Therefore, such new roles have to be clearly defined and their importance have to be communicated in terms of the benefits that arise from creating these roles beyond the core activities of teaching and research. Talent management strategies have to be different for those in Vertical A and Vertical B.

Vertical B focuses on research it is important to create metrics which can differentiate the quantity \& quality of research, as it indirectly affects the reputation of the B School. Those recruited in vertical B need to do more than just publish a large number of papers. The quality of publication, the societal impact of the research and its application to corporate will make it useful to portray the research by a B School. The biggest hurdle is to measure the quality of publication. The quality of publication can be measured using proxy methods like the citation score, impact factor of the journal, the reputation of the publisher etc. There would be difficulty in the metrics to measure societal impact of the research as it occurs outside academia and the same is with the measurement of the actual impact of the research and hence this will need vigilant elucidation (Van Raan 2005). Hence the talent recruitment strategy and talent retention strategy metric for vertical B must just not only focus on the volume of research outcome but also on the quality of the same.

Vertical A focuses not only on teaching and learning, but also on all aspects that are in line with the vision of the B School. The teaching feedback, the revenue generated by consulting, the placement opportunities provided to the students, the corporate engagement that the B School has, the income that the B School generates from management development programmes and consulting assignments that the B School offers to corporate, all play a significant role in measure the effectiveness and efficiency of talent involved in this vertical. The metrics that have to be created for measurement which can be used for talent recruitment and retaining talent must have all these aspects along with the custom created metric which can measure the aspects related to the vision of the B School. Hence distinguishing metrics are needed to identify the high-value individuals and the metrics must also help in rewarding them by measuring the effectiveness and efficiency of the individual's contribution to their respective goals.

\section{Conclusion}

In the ever-changing Indian regulatory environment which regulates the education systems of B Schools in India it can be difficult to justify the metrics developed for identifying, rewarding and retaining talent which can help in having policies which in line with the Vision of the B School and which can help the B School meet the regulatory requirements along with its ranking ambitions. We have seen that presently there is no alignment between the talent management strategy of the B School and its vision. Hence in this paper the authors have suggested for a dual talent management strategy which can help B School to align with the vision and also help in meeting the regulatory objectives and its ranking ambitions. It would be detrimental for the B School in long run, if there is no strategic alignment between its Vision and the talent management strategy. Without this alignment there will be a difference between the B Schools stated objectives (vision) and the outcomes that it delivers to the society. The framework provided can assist in the identification and development of the key people, the pivotal positions and human resources systems required for the B School to deliver on its strategic objectives. It is also critical that the concepts of talent management are applied at all levels of the B School hierarchy and are tailored to the specific goals that are set. 


\section{References}

Abbott, M., \& Ali, E. (2009). The Impact of Exchange Rate Variations and University Reputation on the Choice of Destinations of International Students in Australia and New Zealand. Journal of Economic and Social Policy, 13(1), 7.

AICTE. https://www.aicte-india.org/sites/default/files/AICTE\%20Degree\%20Pay\%2C\%20Qualifications\%20and\%20Pr omotions.pdf.

Armstrong, M. (2006). A Handbook of Human Resource Management Practice (10th ed.). London/Philadelphia: Kogan Page. 982 p.

Ashton, C., \& Morton, L. (2005). Managing talent for competitive advantage: Taking a systemic approach to talent management. Strategic HR Review, 4(5), 28-31. https://doi.org/10.1108/14754390580000819

Basu, A. (2006). Using ISI's 'Highly Cited Researchers' to obtain a country level indicator of citation excellence. Scientometrics, 68(3), 361-375. https://doi.org/10.1007/s11192-006-0117-x

Bradley, D., Noonan, P., Nugent, H., \& Scales, B. (2008). Review of Australian higher education: final report. Australian Government, (DEEWR).

Deem, R. (2001). Globalisation, new managerialism, academic capitalism and entrepreneurialism in universities: is the local dimension still important?. Comparative Education, 37(1), 7-20. https://doi.org/10.1080/03050060020020408

Delaney, J.T., \& Huselid, MA. (1996). The impact of human resource management practices on perceptions of organizational performance. Academy of Management Journal, 39(4), 949-969. https://doi.org/10.2307/256718

Edwards, D., \& Smith, T.F. (2010). 'Supply issues for science academics in Australia: now and in the future'. Higher Education, 60(1), 19-32. https://doi.org/10.1007/s10734-009-9283-0

Gilliot, D., Overlaet, B., \& Verdin, P. (2002). Managing academic personnel flow at universities. Tertiary Education and Management, 8(4), 277-295. https://doi.org/10.1023/A:1021245332632

Goodall, A.H. (2009). Highly cited leaders and the performance of research universities. Research Policy, 38(7), 1079-1092. https://doi.org/10.1016/j.respol.2009.04.002

Harsha, P. P., \& Shah, S. (2011). Creating brand value of higher education institution. IJMT,19(2), 152-158.

Huisman, J., Weert, E., \& Bartelse, J. (2002). Academic careers from a European perspective: the declining desirability of the faculty position. The Journal of Higher Education, 73(1), 141-160. https://doi.org/10.1080/00221546.2002.11777134

Ingham, J. (2006). Closing the talent management gap: Harnessing your employees' talent to deliver optimum business performance. Strategic HR Review, 5(3), 20-23. https://doi.org/10.1108/14754390680000877

Kantabutra, S., \& Avery, G. (2010). The power of vision: statements that resonate. Journal of Business Strategy, 31(1), 37-45. https://doi.org/10.1108/02756661011012769

Kubler, J., \& DeLuca, C. (2006). Trends in Academic Recruitment and Retention: a Commonwealth Perspective, London: The Association of Commonwealth Universities.

Kumar, S., \& Dash, M. K. (2011, January). Management education in India: Trends, issues and implications. Research Journal of International Studies, 18, 15-25.

Lewis, R.E., \& Heckman, R.J. (2006). Talent management: A critical review. Human Resource Management Review, 16(2), 139-154. https://doi.org/10.1016/j.hrmr.2006.03.001

Lin, C., H.L. Tsai, \& J.C. Wu. (2014). Collaboration strategy decision-making using the Miles and Snow typology. Journal of Business Research, 67(9), 1979-1990. https://doi.org/10.1016/j.jbusres.2013.10.013

Lorange, P. (2006). A performance based, minimalist human resource management approach in business schools. Human Resource Management, 45(4), 649-658. https://doi.org/10.1002/hrm.20136

Lubbe, V., \& Larsen, V. (2008). Quick-Scan Jong Talent in De Wetenschap. Probleemanalyse Ten Behoeve Van Het Programma 'Loopbaanperspectief Jong Talent, Utrecht: VSNU.

McCauley, C., \& Wakefield M. (2006). Talent Management in the 21st Century. The Journal of Quality \& Participation, 29(4), 4. 
Metcalf, H., Rolfe, H., Stevens, P., \& Weale, M. (2005). Recruitment and Retention of Academic Staff in Higher Education, Nottingham: National Institute of Economic and Social Research.

MHRD.

https://mhrd.gov.in/phd-degree-will-be-mandatory-direct-recruitment-assistant-professors-universities-wef-0107 2021-shri

Musselin, C. (2005). European academic labor markets in transition. Higher Education, 49, 1-2,135-154.https://doi.org/10.1007/s10734-004-2918-2

NIRF. (2019). https://www.nirfindia.org/Home

Nkomo, S.M. (2009). The seductive power of academic journal rankings: challenges of searching for the otherwise. Academy of Management Learning \& Education, 8(1), 106-112. https://doi.org/10.5465/amle.2009.37012184

Özbilgin, M. (2009). From journal rankings to making sense of the world. Academy of Management Learning \& Education, 8: 1, 113-121

Parker, M., \& Jary, D. (1995). The McUniversity: organization, management and academic subjectivity. Organization, 2(2), 319-338. https://doi.org/10.1177/135050849522013

Porter, M.E. (1985). Competitive Advantage. New York: The Free Press

Sahoo, C., \& Mishra, S. (2012). Performance management benefits organizations and their employees. Human Resource Management International Digest, 20(6), 3-5. https://doi.org/10.1108/09670731211260771

Shah, A. (2012, September). India's business schools get tough lesson in supply and demand. Reuters. Retrieved from http://in.reuters.com/article/2012/09/10/india-education-mbabusiness-schools-idINDEE88900W20120910

Shaikh, S.A. (2009). A survey of migration of academics in higher education and their impact on host institutions. Reflecting Education, 5(1), 16-30.

Sinha, D. P. (2006). Management education in India: Perspectives and challenges. Hyderabad, India: ICFAI University Press, ISBN: 9788178812793.

Tijssen, R., Visser, M., \& van Leeuwen, T. (2002). Benchmarking international scientific excellence: are highly cited research papers an appropriate frame of reference?. Scientometrics, 54(3), 381-397. https://doi.org/10.1023/A:1016082432660

UGC. (2019). https://www.ugc.ac.in/pdfnews/4033931_UGC-Regulation_min_Qualification_Jul2018.pdf.

Van Balen, B., \& van den Besselaar, P. (2007). Universitaire Onderzoeksloopbanen. Een Verkenning Van Problemen En Oplossingen [Academic Careers. An Exploration of Problems and Solutions], Rathenau Instituut SciSa rapport 0702. Den Haag: Rathenau Instituut.

Van den Brink, \& Benschop Yvonne. (2011). Gender practices in the construction of academic excellence: Sheep with five legs. Organization, 19, 507-524. https://doi.org/10.1177/1350508411414293

Van Raan, A. (2005). Statistical properties of bibliometric indicators: research group indicator distributions and correlations. Scientometrics, 57(3), 408-430. https://doi.org/10.1002/asi.20284

Van Raan, A.F.J. (2005). Fatal attraction: Conceptual and methodological problems in the ranking of universities by bibliometric methods. Scientometrics, 62(1), 133-143. https://doi.org/10.1007/s11192-005-0008-6

Verhaegen, P. (2005). Academic talent: 'Quo vadis? Recruitment and retention of faculty in European business schools. Journal of Management Development, 24(9), 807-818. https://doi.org/10.1108/02621710510621312 